\title{
KONDISI PSIKOLOGIS KELUARGA DAN PENGARUHNYA TERHADAP TINGKAT DISIPLIN SISWA
}

\author{
St. Muthahharah \\ Pendidikan Agama Islam Fakultas Agama Islam| Unismuh Makassar \\ Taharahara@yahoo.co.id
}

\begin{abstract}
ABSTRAK
Jenis penelitian yang digunakan bersifat deskriftif kuantitatif, yang beralokasi di Kelurahan Ereng-Ereng Kecamatan Tompobulu Kabupaten Bantaeng, dengan menggunakan pendekatan keilmuan, yaitu pendekatan teologis normatif, paedagogis dan psikologis.Teknik pengambilan sampel yaitu sampel jenuh sebanyak 97 subjek. Teknik pengumpulan data melalui observasi, koesioner, interview, dan dokumentasi. Analisis data dengan langkah-langkah berupa validitas, realibilitas, uji normalitas, linearitas dan uji hipotesis dengan menggunakan rumus regresi linier sederhana dan uji $T$ dengan SPSS 17 for Windows. Berdasarkan hasil analisis data yang dilakukan, maka nilai signifikansi yang diperoleh 0,000, sedangkan nilai $r$ square menunjukkan 0,56 artinya terdapat pengaruh kondisi psikologis keluarga terhadap pembentukan sikap disiplin siswa di Madrasah Aliyah Pondok Pesantren KH. Ahmad Dahlan Muhammadiyah Ereng-Ereng Kabupaten Bantaeng sebesar 56\%. Adapun $44 \%$ kedisiplinan siswa.
\end{abstract}

Kata kunci: Kondisi Psikologis Keluarga, Tingkat Disiplin Siswa

\section{ABSTRACT}

The purpose of this research is to find and analyze the influence of family psychological condition of the formation of the discipline of students in Madrasah Aliyah boarding school KH. Ahmad Dahlan Muhammadiyah Ereng-Ereng, Bantaeng. This type of research is descriptive quantitative, which located in Subleaning leaning District of Tompobulu Bantaeng, using a scientific approach, the normative theological approach, pedagogical and psychology. Technique sampling is saturated sample of 97 subjects. Technique collecting data are through observation, questioner, interview, and documentation. Analysis of data by measures such as validity, reliability, test for normality, linearity and hypothesis testing using simple linear regression formula and T test with SPSS 17 for Windows. Based on the results of the data analysis, the significant value gained 0,000, while the $r$ value of 0.56 means that there are square shows the influence of family psychological condition of the formation of the discipline of students in Madrasah Aliyah boarding school KH. Ahmad Dahlan Muhammadiyah Ereng-ereng Bantaeng by 56\%. The 44\% are discipline of students

Keywords: psychological condition of the family, the level of student discipline 


\section{PENDAHULUAN}

Kedisiplinan merupakan salah satu aspek yang mendukung keberhasilan dalam proses pembelajaran untuk mencapai tujuan pendidikan. Sebab keberhasilan pendidikan tidak hanya tergantung pada metode dan keterampilan seorang guru dalam menyajikan materi pelajaran, tetapi juga sangat ditentukan oleh kedisiplinan peserta didik dalam menerima pelajaran baik di sekolah maupun di luar sekolah. Masalah kedisiplinan adalah upaya yang dilaksanakan untuk menunjang keberhasilan dalam meningkatkan prestasi belajar peserta didik, sedangkan proses pembentukan awal kedisiplinan anak merupakan tugas keluarga.

Menurut As'aril Muhajir (2011:136), keluarga adalah bagian dari kehidupan sosial seseorang, dan menjadi bagian sangat penting yang memengaruhi seluruh kehidupan sehingga merupakan representasi dari keseluruhan kehidupan seseorang. Uraian tersebut dapat dipahami bahwa keluarga sangat besar perananya dalam membentuk, melatih dan mengembangkan sikap disiplin anak, karena lingkungan keluarga merupakan kelompok sosial yang petama dalam kehidupan manusia, sebelum individu berinteraksi dengan sesama di lingkungan sosial dalam lingkup yang lebih luas. Selama berinteraksi dengan sesama anggota keluarga, terjadi proses belajar baik secara fisik maupun psikis. Aspek luar yang memengaruhi keluarga sangat besar, seperti era globalisasi yang ditandai dengan kemajuan ilmu pengetahuan dan teknologi, selain berdampak positif juga berdampak negatif.
Keluarga adalah lingkungan yang pertama dan utama bagi perkembangan anak. Dalam keluarga seorang anak mengalami proses sosialisasi untuk pertama kalinya, dalam proses ini seorang anak diajarkan dan dikenalkan berbagai nilai kehidupan yang sangat berguna dan menentukan bagi perkembangan anak di masa depan. Suasana keluarga yang harmonis dan menyenangkan akan mendorong anak giat atau berdisiplin dalam belajar. Sedangkan Abuddin Nata (2010:115), mengungkapkan bahwa terdapat sejumlah fakta yang menunjukkan perilaku seseorang dimasa dewasa sangat ditentukan oleh pendidikan yang mereka terima dimasa kanak-kanak. Seorang anak yang dimasa kecilnya dibina dengan kasih sayang, kehangatan cinta, dan perhatian yang penuh dari kedua orang tuanya jauh berbeda dengan anak yang dimasa kecilnya tidak pernah merasakan kasih sayang atau kehangatan dari orang tuanya.

Disiplin diri merupakan aspek utama dan esensial pada pendidikan dalam keluarga yang diemban oleh orang tua, karena orang tua bertanggung jawab secara kodrati dalam meletakkan dasar-dasar dan pondasi kepada anak-anak. Upaya orang tua atau pendidik akan tercapai jika anak telah mampu mengontrol perilakunya sendiri dengan acuan pada nilai-nilai moral yang terinternalisasi. Orang tua perlu menciptakan situasi dan kondisi yang dapat mengundang anak berdialog dengan mereka sejak usia dini agar anak menyadari moral sebagai landasan keteraturan disiplin dirinya. Moh. Shochib (2010:9), mengungkapkan bahwa, orang tua mempunyai tanggungjawab kodrati yang sangat strategis posisinya dalam 
menghadirkan situasi dan kondisi yang bermuatan nilai moral untuk dihayati dan diapresiasi oleh anak-anak. Oleh sebab itu, sadar moral menjadi landasan disiplin diri yang harus dikembangkan.

Depertemen

Pendidikan (2011:11), Undang-Undang RI Nomor. 20 Tahun 2003 tetang Sistem Pendidikan Nasiona, Pasal 7 poin (1) yaitu: orang tua berhak berperan serta dalam memilih satuan pendidikan dan memperoleh informasi tentang perkembangan pendidikan anaknya. (2) Orang tua dari anak usia wajib belajar, berkewajiban memberikan pendidikan dasar kepada anaknya. Isi dari poin undang-undang tersebut dapat dipahami bahwa betapa besar peranan keluarga khususnya orang tua dalam memenuhi kebutuhan pendidikan anak-anaknya sebagai peletak awal nilai-nilai kebaikan dalam kehidupan sosial termasuk penanaman kedisiplinan anak.

Anak yang berdisiplin diri memiliki keteraturan diri berdasarkan nilai agama, moral, nilai budaya, aturan-aturan pergaulan, pandangan hidup, dan sikap hidup yang bermakna bagi dirinya sendiri, masyarakat, bangsa dan negara. Orang tua bertanggung jawab membentuk, melatih, membiasakan dan mengupayakan agar anak memiliki sikap disiplin diri dalam melaksanakan hubungan dengan Tuhan yang menciptakan dirinya sendiri, sesama manusia, lingkungan alam dan makhluk hidup lainnya berdasarkan nilai-nilai agama. Pada akhirnya anak tersebut mampu mengaplikasikan kebiasaan bersikap disiplin diri pada saat berada di lingkungan sekolah dengan menaati peraturan atau tata tertib sekolah.

\section{Pokok Permasalahan}

Pokok permasalahan dalam penelitian ini adalah: bagaimana gambaran perilaku disiplin siswa di Madrasah Aliyah Pondok Pesantren KH. Ahmad Dahlan Muhammadiyah Ereng-Ereng Kabupaten Bantaeng?, bagaimana gambaran kondisi psikologis keluarga siswa di Madrasah Aliyah Pondok Pesantren KH. Ahmad Dahlan Muhammadiyah Ereng-Ereng Kabupaten Bantaeng?, Apakah kondisi psikologis keluarga berpengaruh terhadap pembentukan sikap disiplin siswa di Madrasah Aliyah Pondok Pesantren KH. Ahmad Dahlan Muhammadiyah Ereng-Ereng Kabupaten Bantaeng? Apakah ada perbedaan tingkat kedisiplinan dan kondisi psikologis keluarga siswa antara jenis kelamin laki-laki dan perempuan di Madrasah Aliyah Pondok Pesantren KH. Ahmad Dahlan Muhammadiyah Ereng-Ereng Kabupaten Bantaeng?

\section{METODELOGI PENELITIAN}

Jenis penelitian yang digunakan bersifat deskriftif kuantitatif, untuk mengungkapkan fakta yang berkaitan pengaruh kondisi psikologis keluarga terhadap pembentukan sikap disiplin siswa pada objek penelitian.

Lokasi penelitian adalah di Madrasah Aliyah Pondok Pesantren KH. Ahmad Dahlan Muhammadiyah Ereng-Ereng Kabupaten Bantaeng. Populasi dalam penelitian ini adalah seluruh peserta didik, kepala sekolah, dan guru di Madrasah Aliayah Pondok Pesantren KH. Ahmad Dahlan Muhammadiyah Ereng-Ereng Kab. Bantaeng. Sampel dalam penelitian ini diambil dari seluruh populasi atau 
siswa yang ada di objek penelitian dengan teknik pengambilan sampling jenuh yaitu teknik penentuan sampel bila semua anggota populasi digunakan sebagai sampel, pada objek penelitian terdapat 97 subjek.

Teknik pengumpulan data yang digunakan oleh peneliti adalah dengan menyebarkan skala/angket, observasi, wawancara, dan dokumentasi. Untuk menganalisis data yang dikumpulkan setiap variabel digunakan analisis statistik deskriptip untuk menjawab pokok masalah pertama dan kedua, dan analisis statistik dengan menggunakan rumus regresi linier sederhana (dengan bantuan program statistik SPSS 17 for windows) untuk menjawab pokok masalah ketiga. Adapun rumus yang digunakan sebagai berikut:

$$
\mathrm{Y}=\mathrm{a}+\mathrm{bX}
$$

Keterangan:

$\mathrm{Y}=$ Variabel terikat (sikap disiplin anak)

$\mathrm{X}=$ Variabel bebas (pengaruh psikologi keluarga)

$$
\begin{aligned}
\mathrm{a}= & \text { Konstanta } \\
\mathrm{b}= & \text { Koefiesiensi hubungan } \\
& \text { pengaruh psikologis } \\
& \text { keluarga terhadap } \\
& \text { pembentukan disiplin } \\
& \text { anak }
\end{aligned}
$$

Sedangkan untuk menjawab pokok masalah keempat peneliti menggunakan analisis deskriptif dengan rumus uji $\mathrm{T}$.

\section{HASIL PENELITIAN DAN ANALISIS}

Deskriptif sikap disiplin diperoleh dari hasil respon atau jawaban subjek terhadap skala yang diberikan, berdasarkan kategorisasi diperoleh data yaitu model sebaran frekuensi sikap disiplin pada kelompok tinggi memiliki interval skor 91-132, kelompok sedang memiliki interval skor 61-90, sedangkan kelompok rendah memiliki interval skor 33-60. Berdasarkan kategorisasi di atas juga didapatkan bahwa tidak terdapat subjek $(0 \%)$ yang memiliki tingkat skor rendah, terdapat subjek $(22,68 \%)$ memiliki tingkat disiplin sedang, dan (77, $13 \%)$ memiliki tingkat disiplin dengan kategori tinggi. Hasil interpertasi dan kategorisasi skor sikap disiplin siswa pada objek penelitian berdasarkan olah data yang diakukan berada pada tingkat disiplin kategori tinggi yaitu sebesar 77, $13 \%$.

Adapun gambaran deskripsi data psikologis keluarga berdasarkan kategorisasi dan interpretasi di atas diperoleh data yaitu model sebaran frekuensi kondisi psikologis keluarga pada kelompok sangat baik memiliki interval skor antara 91-132, kelompok sedang memiliki interval skor antara 61-90, sedangkan kelompok rendah memiliki interval skor antara 33-60. Berdasarkan kategorisasi di atas juga diperoleh data bahwa tidak terdapat subjek $(0 \%)$ yang memiliki tingkat kondisi psikologis keluarga rendah, terdapat subjek dengan tingkat kondisi psikologis keluarga sedang dengan persentase 28, $86 \%$, dan $71,13 \%$ yang memiliki kondisi psikologis keluarga. Hal ini berarti skor kondisi psikologis keluarga pada subjek penelitian dikategorikan sangat baik.

Uji prasyarat dilakukan sebelum melakukan uji hipotesis, yang meliputi uji normalitas dan linearitas. Untuk uji normalitas ini dilakukan dengan menggunakan uji linieritas dan dibantu dengan menggunakan Software SPSS.17(Statistical Package for the Sosial Science). Syarat normal jika nilai Asymp. Sig. (2-tailed)> 0.1 
Kolmogorov-Smirnov $\mathrm{Z}$ merupakan angka $Z$ yang dihasilkan dari teknik Kolmogorov Smirnov untuk menguji kesesuaian distribusi data kita dengan suatu distribusi tertentu, dalam hal ini distribusi normal. Hipotesis untuk pengujian normalitas adalah:

$\mathrm{H}_{0}$ : Sampel berasal dari populasi berdistribusi normal

$\mathrm{H}_{1}$ : Sampel tidak berasal dari populasi berdistribusi normal

Asymp. Sig. (2-tailed). merupakan nilai $\mathrm{p}$ yang dihasilkan dari uji hipotesis nol yang berbunyi tidak ada perbedaan antara distribusi data yang diuji dengan distribusi data normal. Jika nilai $\mathrm{p}$ lebih besar dari 0,1 ( $\mathrm{p}>0,1)$ maka kesimpulan yang diambil adalah hipotesis nol gagal ditolak, atau dengan kata lain sebaran data yang kita uji mengikuti distribusi normal.

Berdasarkan tabel tersebut diatas, nilai signifikansi atau $\mathrm{p}=0,648$ $(0,648>0,1)$, maka dapat disimpulkan bahwa sebaran data untuk variable psikologis keluarga (X) berdistribusi normal. Sedangkan pada variabel sikap disiplin anak (Y) adalah sebesar 0, 793 $(0,793>0,1)$ maka dinyatakan berdistribusi normal.

Uji Linearitas, asumsi linearitas adalah asumsi yang akan memastikan apakah data yang kita miliki sesuai dengan garis linear atau tidak. Asumsi ini dapat diketahui dengan mencari nilai deviation from linearty dari uji $\mathrm{F}$ linear. Berdasarkan tabel rangkuman hasil uji linearitas menunjukkan bahwa signifikansi pada nilai $\mathrm{p}$ lebih kecil dari nilai linearty $\mathrm{F}(0,00<0,05)$, sedangkan nilai $\mathrm{F}$ deviation from linieritylebih besar dari $0,05 \mathrm{~F}(0,453>$ $0,05)$, berdasarkan hasil tersebut dapat disimpulkan bahwa pengaruh psikologis keluarga terhadap pembentukan sikap disiplin anak adalah linier.

Pengujian hipotesis analisis regresi digunakan untuk mengetahui pengaruh kondisi psikologis keluarga terhadap pembentukan sikap disiplin siswa di objek penelitian. Berdasarkan hasil analisis data yang dilakukan, maka nilai F 123,08, signifikansi 0,000dan nilai $\mathrm{r}$ square menunjukkan 0,56 artinya bahwa pengaruh psikologis keluarga terhadap pembentukan sikap disiplin anak di Madrasah Aliyah Pondok Pesantren KH. Ahmad Dahlan Muhammadiyah Ereng-Ereng Kabupaten Bantaeng memiliki pengaruh 56\%. Adapun sisanya sebesar $44 \%$ kedisiplinan peserta didik dipengaruhi oleh faktorfaktor yang lain dan tidak menjadi objek kajian dalam penelitian ini.

Berdasarkan tabel rangkuman hasil olah data berdasarkan jenis kelamin menunjukkan bahwa kondisi psikologis keluarga dan disiplin anak untuk jenis kelamin perempuan lebih tinggi dibanding laki-laki, pada variabel psikologis keluarga jenis kelamin laki-laki memperoleh Standar Deviasi (SD) 8, 20 dan perempuan SD 8,59 dengan taraf signifikansi 0,810 . Sedangkan variabel disiplin jenis kelamin laki-lakimemperoleh SD 9,44 dan perempuan SD 9,70 dengan taraf signifikansi 0,898.

Berdasarkan hasil oleh data berdasarkan kelompok kelas menunjukkan bahwa kondisi psikologis keluarga berdasarkan kelompok kelas $\mathrm{X}$ dengan Standar Deviasi (SD) 8,25, kelas XI SD 7,60 dan kelas XII dengan SD 8,19. Hal tersebut berarti kondisi psikologis keluarga kelas X lebih tinggi dibanding dengan kelas yang lain. Sedangkan kondisi disiplin siswa dapat dilihat 
pada tabel di atas menunjukkan disiplin kelas X SD 9,41, kelas XI SD 9,41 dan kelas XII SD 9,60. Dengan demikian sikap disiplin anak pada kelas XII lebih tinggi dibanding dengan kelas XI dan kelas X. Namun, tidak terlihat perbedaan yang sangat signifikan karena hasil olah data baik variabel kondisi psikologis keluarga maupun disiplin anak menunjukkan taraf signifikansi yang sama yaitu 0,002 .

Kedisiplinan merupakan salah satu unsur penentu keberhasilan seseorang dalam meraih cita-cita yang diharapakan, seorang siswa, pelajar/peserta didik tentunya tidak akan mendapatkan prestasi yang tinggi ketika tidak disiplin dalam belajar. Begitu pula dalam sebuah lembaga pendidikan (sekolah/madrasah) tidak akan tercipta suasana belajar yang sehat, kondusif dan efektif serta efesien dalam lingkungan sekolah ketika semua unsur yang ada di dalamnya tidak disiplin baik mulai dari pimpinan, para guru, staf, terlebih lagi peserta didik. Dalam lingkungan sekolah salah satu upaya untuk mendisiplinkan para peserta didik tentunya dengan pelaksanaan aturanaturan yang tertuang dalam bentuk tata tertib sekolah. Tata tertib inilah yang harus diikuti dan ditaati oleh seluruh peserta didik, tentunya dengan penegakan aturan-aturan tersebut secara ketat, konsisten dan kentinyu dari pihak sekolah akan membuat seluruh peserta didik mau atau tidak harus menaatinya.

Pengawasan dan pengontrolan perilaku peserta didik dari pimpinan dan para guru juga akan sangat mempengaruhi siswa dalam menjalankan kewajibannya. Hal ini dilakukan agar semua proses pendidikan berjalan dengan baik sesuai dengan yang diharapkan yang pada akhirnya akan mempengaruhi juga prestasi belajar siswa. Masalah pendisiplinan anak bukan hanya menjadi tugas para pendidik yang ada di sekolah, akan tetapi proses pembentukan awal disiplin berada di lingkungan keluarga. Dalam hal ini orang tua atau wali anak bertanggung jawab besar dalam melakukan upayaupaya agar anak mampu menjadi pribadi yang berdisiplin tinggi, dengan menanamkan nilai-nilai agama, moralitas pada diri anak serta melakukan kontrol, pengawasan terhadap perilaku anak, membangun komunikasi yang sehat, memberikan dukungan dan pelibatan orang tua terhadap anak.

Nilai-nilai yang ditanamkan oleh orang tua dalam diri anak, sejatinya akan membentuk pribadi yang positif dan berdisiplin tinggi. Nilai-nilai tersebut juga diharapkan mampu diejawantahkan anak dalam kehidupa sehari-harinya baik dalam lingkungan sekolah dengan mematuhi peraturan-peraturan yang berlaku, serta dalam lingkungan sosial masyarakat dalam bentuk menjalankan normanorma yang ada. Orang tua, pendidik atau guru serta masyarakat memiliki tanggung jawab dalam menanamkan, mengembangkan dan mempertahankan kedisiplinan anak tentunya sesuai dengan peran dan fungsi masingmasing.

\section{KESIMPULAN}

Hasil penelitian ini dapat ditarik beberapa kesimpulan sebagai berikut:

1. Hasil penelitian menunjukkan tentang gambaran umum perilaku disiplin siswa yang 
terdapat di objek penelitian bahwa pada dasarnya para peserta didik menunjukkan disiplin dengan tingkat persentase $77 \%$.

2. Gambaran deskriptif kondisi psikologis keluarga pada objek penelitian, sebagaimana hasil olah data menunjukkan bahwa skor frekuensi dan persentase dari skala kondisi psikologis yang disebar sebesar (F) 69 dan (P) 71, $13 \%$. Hal ini menunjukkan bahwa kondisi psikologis keluarga dari subjek penelitian $71 \%$ dengan kategorisasi sangat baik, sedangkan untuk kategori sedang sebesar 28, $86 \%$.

3. Hasil olah data yang dilakukan melalui skala yang disebar kepada sampel penelitian dengan dua variabel yaitu kondisi psikologis keluarga dan sikap disiplin siswa, menunjukkan bahwa terdapat pengaruh yang positif kondisi psikologis keluarga terhadap pembentukan sikap disiplin siswa di Madrasah Aliyah Pondok Pesantren KH. Ahmad Dahlan Muhammadiya Ereng-Ereng Kabupaten Bantaeng dengan perolehan $r^{2}$ menunjukkan 0,56 , hal tersebut berarti bahwa sebesar $56 \%$ psikologis keluarga mempengaruhi pembentukan sikap disiplin anak. $44 \%$ kedisiplinan anak dipengaruhi oleh variabel lain yang tidak menjadi fokus dalam penelitian ini.

4. Hasil analisis data untuk mengetahui tingkat kondisi psikologis keluarga dan kedisiplinan siswa berdasarkan perbedaan jenis kelamin pada objek penelitian ditemukan taraf signifikansi 0,810 dan diperoleh nilai $F \quad 0,058$ dengan kondisi psikologis keluarga jenis kelamin laki-laki memperoleh mean 120,49 dan perempuan mean 121,19. Sedangkan variabel kedisiplinan diperoleh taraf signifikansi 0,898 , dan nilai $\mathrm{F}$ 0,016 dimana jenis kelamin lakilaki memperoleh mean 111,11 dan perempuan 113,56. Berdasarkan kategorisasi menunjukan bahwa jenis kelamin perempuan memiliki kondisi psikologis keluarga rata-rata sangat baik, dan kedisiplinan dikategorikan rata-rata tinggi jika dibandingkan dengan jenis kelamin laki-laki.

\section{DAFTAR PUSTAKA}

Depertemen Pendidikan.UndangUndang Sistem Pendidikan Nasional.Cet. IV; Yogyakarta, Pustakia Pelajar, 2011.

Muhajir, As'aril. Ilmu Pendidikan Persfektif Kontekstual. Cet. I; Jogjakarta: Ar-Ruzz Media, 2011

Nata, Abuddin. Ilmu Pendidikan Islam.Cet. I; Jakarta: Kencana Prenada Media Group, 2010.

Shochib, Moh. Pola Asuh Orang Tua, dalam Membantu Anak Mengembangkan Disiplin Diri. Cet.II; Jakarta, Rineka Cipta, 2010. 